\title{
Frequency of estrus in Santa Inês, Texel and lle de France ewes in the northwest of Paraná State, Brazil
}

\section{Gentil Vanini de Moraes ${ }^{1}$, Francisco de Assis Fonseca de Macedo ${ }^{1}$, Fábio José Lourenço², Filipe Gomes de Macedo ${ }^{3}$, Luiz Paulo Rigolon ${ }^{1}$, Guilherme de Paula Nogueira ${ }^{4}$, Graziela Aparecida Santello 5}

\author{
${ }^{1}$ Departamento de Zootecnia, Universidade Estadual de Maringá, Maringá, PR, Brasil. \\ 2 Departamento de Medicina Veterinária, Centro Universitário de Maringá, Maringá, PR, Brasil. \\ ${ }^{3}$ Programa de Pós-Graduação em Zootecnia, Universidade Estadual de Maringá, Maringá, PR, Brasil. \\ ${ }^{4}$ Departamento de Zootecnia, Universidade Estadual Paulista, Botucatu, SP, Brasil. \\ ${ }^{5}$ Instituto de Ciências Sociais, Educação e Zootecnia, Universidade Federal do Amazonas, Parintins, AM, Brasil.
}

\begin{abstract}
The incidence of estrus in nulliparous Santa Inês $(n=16)$, Texel $(n=16)$ and Ile de France $(n=15)$ ewes fed two levels of crude protein (CP, 12 or 16\%) was monitored from July 2005 to December 2006, and seasonality in the Santa Inês breed in the south of Brazil was characterized. The solar radiation data were recorded daily, and samples of blood were collected biweekly for determination of the plasma concentration of progesterone in Santa Inês lambs at, on average, $11 \pm 1$ months of age. The female Santa Inês lambs, in the experimental period, stayed among teaser rams with a powdered-dye-ink mixture placed on their chest to mark the females that accepted to be mounted. Santa Inês ewes did not manifest estrus in the first fortnight of November and in December 2005, nor in the last fortnight of December 2006. Estrus activity was not observed on any of the three breeds in October 2006. Breeds differed at the level of 12\% CP. Santa Inês and Ile de France females did not differ as for the probability estrus manifestation and both presented higher probabilities then Texel. When the effect of 12 or $16 \% \mathrm{CP}$ on each breed was evaluated separately, it was verified that levels of 12 or $16 \%$ of crude protein did not change the probability of estrus manifestation in any of the studied breeds. The concentration of plasma progesterone in Santa Inês ewes during the spring of 2005 and 2006 indicated that there is difference between $12 \% \mathrm{CP}(0.68 \pm 1.32 \mathrm{ng} / \mathrm{mL}) \mathrm{and} 16 \% \mathrm{CP}$ $(1.28 \pm 1.99 \mathrm{ng} / \mathrm{mL})$ and between the years $2005(0.39 \pm 0.78 \mathrm{ng} / \mathrm{mL})$ and $2006(1.47 \pm 2.08 \mathrm{ng} / \mathrm{mL})$, demonstrating the anestrous seasonality of Santa Inês in South Brazil.
\end{abstract}

Key Words: photoperiodic, progesterone, reproduction, seasonality

\section{Introduction}

Sheep are classified as seasonal polyestrous animals, characterized by presenting defined reproductive seasons, manifesting estrous on days of decreasing photoperiod (Goldman, 1999).

Latitude is one of the most important factors in the variation of light, as can be observed in the summer and winter solstices, and sheep also tend to manifest estrus throughout the entire year when near the Equator (Galina et al., 1996).

In the Brazilian northeast, there is a greater concentration of woolless ewes, which manifest estrus year round (Silva et al., 1987), while in the south and southeast of Brazil, there are wool and woolless sheep and various degrees of seasonality (Roda et al., 1993).

The fact that Santa Inês ewes are fertile all year long has drawn the attention of technicians and producers, generating a strong move of migration of animals of this breed to several regions of Brazil, including the south and southeast. However, the behavior of animals brought from low to high latitudes has not yet been studied in detail, and the first studies demonstrate that change of photoperiod had no effect on the cyclic behavior of Santa Inês ewes. Sasa (2006) reports that despite being considered annual polyestrous animals, Santa Inês present periods (although short) of reproductive seasonality.

Nutrition also plays an important role in sheep reproduction traits, such as age at puberty, fertility, ovulation rate, embryo survival and production of spermatozoa (Rhind, 1992; Robinson, 1996), and protein is the second most important ingredient that makes up diets.

The present study was developed to verify the frequency of manifestation of estrus and the effect of crude protein levels in the diet of Santa Inês, Texel and Ile de France ewes and to characterize the existence of seasonal periods in female Santa Inês sheep in the south region of Brazil. 


\section{Material and Methods}

The experiment was carried out at Centro de Pesquisa do Arenito da Universidade Estadual de Maringá (UEM), in the municipality of Cidade Gaúcha/PR, Brazil, located at $23^{\circ} 25^{\prime}$ South latitude, $51^{\circ} 55^{\prime}$ West longitude and $554.9 \mathrm{~m}$ altitude. The climate is a predominant mesothermal subtropical humid type with hot summers, infrequent frosts, with tendencies of concentration of rain in the summer months, and a Red-Yellow Podzolic soil of medium texture (Corrêa, 1996). The experiment was carried out from July 2005 to December 2006. Solar radiation was obtained by a local micro-meteorological station, presenting average $848.65 \mathrm{w} . \mathrm{m}^{-2}$ in the winter, $1,133.75 \mathrm{w} . \mathrm{m}^{-2}$ in the spring, $1,197.83 \mathrm{w} \cdot \mathrm{m}^{-2}$ in the fall and $1,096.83 \mathrm{w} \cdot \mathrm{m}^{-2}$ in the summer.

Forty-seven nulliparous ewes at initial age of approximately $11 \pm 1$ months and $29 \pm 1$ months at the end of the experimental periods, with average initial weights of $38.2 \pm 1.7 ; 40.1 \pm 1.9$; and $51.4 \pm 1.15 \mathrm{~kg}$, and average final weights of $44 \pm 1.4 ; 49 \pm 2.0 ; 66 \pm 1.4 \mathrm{~kg}$, of the Santa Inês $(\mathrm{n}=16)$, Texel $(\mathrm{n}=16)$ and Ile de France $(\mathrm{n}=15)$ breeds, respectively, were used for the experiment. Animals were randomly divided in breeds and distributed in a group with a diet containing 12 or $16 \%$ of crude protein (CP).

The diets with $12 \%$ or $16 \% \mathrm{CP}$ were formulated according to the NRC (1985), containing $60 \%$ TDN, and dry matter intake was estimated at $25 \mathrm{~g} / \mathrm{kg}$ body weight.

Ewes were kept from $09 \mathrm{~h} 00$ to $17 \mathrm{~h} 00$ in three paddocks of 1 ha each, formed with Aruana grass (Panicum maximum cv. IZ-5) pasture, in a monthly-rotation system, containing $25.6 \mathrm{~g}$ crude protein $/ \mathrm{kg}$.

From $07 \mathrm{~h} 30$ to $09 \mathrm{~h} 00$, the animals on the diet with $12 \% \mathrm{CP}$ received $230 \mathrm{~g}$ soybean meal, and those fed the diet with $16 \% \mathrm{CP}$ received $350 \mathrm{~g}$ of it. In late afternoon, the ewes fed the diet with $12 \% \mathrm{CP}$ were also fed $180 \%$ of cassava starch residue (DM) at the proportion of $14 \%$ of the total diet in the dry matter (DM). Mineral salt Ovinophos $\left(\right.$ Tortuga $^{\circledR}$ ) was offered ad libitum in troughs located within the facility. The guarantee levels of the salt are: $147 \mathrm{~g} \mathrm{Na}$; $120 \mathrm{Ca}^{+} ; 87 \mathrm{~g} \mathrm{P} ; 18 \mathrm{~g} \mathrm{~S} ; 3,800 \mathrm{mg} \mathrm{Zn} ; 1,800 \mathrm{mg} \mathrm{Fe} ; 1,300 \mathrm{mg} \mathrm{Mn}$; $1,300 \mathrm{mg}$ monensin sodium; $870 \mathrm{~g} \mathrm{~F} ; 590 \mathrm{mg} \mathrm{Cu} ; 300 \mathrm{mg} \mathrm{Mb}$; $80 \mathrm{mg} \mathrm{I} ; 40 \mathrm{mg} \mathrm{Co} ; 20 \mathrm{mg} \mathrm{Cr}$; and $15 \mathrm{mg} \mathrm{Se}$.

Ewes were wormed and vaccinated against clostridial diseases thirty days prior to the beginning of data collection and weighed monthly to adjust the quantity of feed supplied so as to meet the proposed nutritional levels. Endoparasite infection was monitored biweekly by counting the eggs per gram of feces (EPG), and worming the animals when they reached counts above $1000 \mathrm{EPG}$ (Lourenço, 2006).
In the experimental period, females remained with vasectomized teaser rams with reduced internal preputial diameter (Aanes \& Rupp, 1984). The teaser rams were daily impregnated with a mixture of powdered dye ink and mutton tallow so facilitate the identification of the females that would accept mounting. The females marked by the teasers were identified and the dates of estrus manifestation were recorded.

Blood samples of ewes were collected biweekly to determine the plasma progesterone concentration. Samples were obtained by venipuncture of the jugular vein with a $40 \times 12 \mathrm{~mm}$ needle (Becton \& Dickinson, United Kingdom). The blood was collected in sterile test tubes containing EDTA. Immediately after collection, test tubes were conditioned in an isothermal container with ice. Samples were taken to the laboratory and centrifuged at 4,444 x $g$ (LS Lodgen - model DES16/RV) per minute for 10 minutes, and the plasma was separated and conditioned in $2 \mathrm{~mL}$ Eppendorf tubes, which were frozen at $-20^{\circ} \mathrm{C}$.

At the end of the phase of data and sample collection, blood plasma samples were analyzed for determination of the progesterone concentration by the radioimmunoassay method (RIE), using Progesterone Coat-A-Count ${ }^{\circledR}$ RIA Kit. The average intra- and inter-assay coefficients of variation obtained were 2.63 and $1.76 \%$, respectively.

The statistical analyses of the data of frequency of estrus were performed through the Bayesian procedure. It was considered that the observations follow a logistic distribution, i.e., a model of random effects with logistic link function. Considering the probability of estrus of animal $i$ at occasion $j$, represented by $\theta_{i j}$, the function of $Y_{i j}$ probability will be given by:

$\mathrm{f}\left(\mathrm{Y}_{\mathrm{ij}}=y_{i j}\right)=\theta_{i j}^{y_{i j}}\left(1-\theta_{i j}\right)^{1-y_{i j}}=\left\{\begin{array}{cl}\theta_{i j} & \text { for } y_{i j}=1 \\ 1-\theta_{i j} & \text { for } y_{i j}=0\end{array}\right.$.

When considering a logistic link function, generally $t_{j}$, the probability of estrus will be given by:

$\theta_{i j}=\frac{\exp \left\{\alpha_{\mathrm{ij}}+\beta_{i j} t_{j}\right\}}{1+\exp \left\{\alpha_{\mathrm{ij}}+\beta_{i j} t_{j}\right\}}$,

so that

$\operatorname{logit}\left(\theta_{i j}\right)=\alpha_{i j}+\beta_{i j} t_{j}$,

where $\alpha_{i j}=\alpha_{I}$ random effect of individual $i$ for any occasion; and $\beta_{i j}=\beta_{i}$ : regression coefficients of individual $i$ for any occasion.

Biologically, parameters $\alpha$ and $\beta$ represent for the animal, respectively, the onset and evolution of the estrus phenomenon.

For the Bayesian modeling, a priori normal distributions were considered for $\alpha$ and $\beta$, so that: $\alpha_{i} \sim N\left(0, \sigma_{\alpha}^{2}\right)$ and $\beta_{i} \sim N\left(0, \sigma_{\beta}^{2}\right)$, assuming a hierarchical structure, where 
hyperparameters $\sigma_{\alpha}^{2}$ and $\sigma_{\beta}^{2}$ are obtained by precision $\tau,(\sigma=1 / \sqrt{\tau})$, obtained by a noninformative a priori Gamma distribution: $\tau \sim \operatorname{Gama}\left(10^{-3}, 10^{-3}\right)$, which are values that characterize a vague distribution, according to the parameterization of the software utilized - WinBUGS, from Spiegelhalter et al. (1995).

For the comparisons between the parameters of the curves between breeds, considering a specific diet, for each parameter, 30,000 values were generated with procedure MCMC (Monte Carlo Markov Chain), considering a sampling-discard period of 1,000 initial values. The final sample taken with jumps of 5 generated values had one taken to belong to the sample, which contains 5,800 generated values. For the comparisons between the curve parameters between diets, considering a specific breed, for each parameter, 200,000 values were generated, considering a sampling-discard period of 1,000 initial values. The final sample taken with jumps of 5 contains 39,800 generated values. The convergence of chains was verified by software CODA (Best et al., 1995), by the criteria of Geweke (1992) and of Heidelberger \& Welch (1983).

The symmetry of conditional marginal distributions of the parameters of interest of each animal was observed, to choose for the a posteriori mean or median, so the overall mean of the statistics was calculated in order to present a single curve for each studied group $\bar{\alpha}=$ mean $\left(\alpha_{i}\right)$ and $\bar{\beta}=$ mean $\left(\beta_{i}\right)$, thus the mean curve is given by:

$\operatorname{logit}\left(\bar{\theta}_{j}\right)=\bar{\alpha}+\bar{\beta} t_{j}$

By the contrasts between the a posteriori distribution of the parameters of the mean curves in the analyzed groups, it was verified, at level $\alpha=5 \%$, if there were significant differences. If the zero value " 0 " is not within the Credible Interval (percentages of $2.5 \%$ and $97.5 \%$ ) of contrast $\Delta, \operatorname{ICr}[\Delta,(1-\alpha) \%]$, the difference between the parameters analyzed is verified.

For the statistical analyses of the plasma progesterone concentration, the software utilized was SAS (Statistical Analysis System, version 9.3), considering the significance level of $5 \%$ by the Tukey test as the following model:

$$
\mathrm{Y}_{i j k}=\mu+\mathrm{T}_{i}+\mathrm{A}_{j}+\mathrm{TA}_{i j}+\mathrm{e}_{i j k} \text {, where: }
$$

$\mathrm{Y}_{i j k}=$ observation of repetition $k$ in treatment $i$ regarding year $j ; \mu=$ overall mean; $\mathrm{T}_{i}=$ effect of diet $i$, where $i=1$ $(12 \% \mathrm{CP})$ or $2(16 \% \mathrm{CP}) ; \mathrm{A}_{j}=$ effect of year of observation $j$, where $j=1$ (2005) or 2 (2006); $\mathrm{TA}_{i j}=$ interaction effect between diet $i$ and year $j ; \mathrm{e}_{i j k}=$ random error associated with each observation $\mathrm{Y}_{i j k}$.

\section{Results and Discussion}

In absolute numbers, the frequency of estrus manifestation decreased in the increasing period of solar radiation and increased in the decreasing solar radiation period (Figure 1). Texel were the most responsive ewes to solar radiation and photoperiod in comparison with Santa Inês and Ile de France.

There was no estrus manifestation in Santa Inês ewes in October or in the first fortnight of November 2005, nor was there estrus manifestation in December 2005 or in the first fortnight of January 2006. On October 1st 2006, no estrus manifestation was verified for any of the studied breeds.

In the last fortnight of December 2006, Santa Inês ewes once again stopped showing estrus, whereas this event was observed in Ile de France ewes.

The analysis of frequency of estrus was performed considering the breeds within the experimental groups fed diets with 12 or $16 \% \mathrm{CP}$, as well as each CP content within the three breed groups studied.

The analysis of frequency of estrus did not show significant effect of crude protein content in the diet. However, it did indicate significant effect of the interaction between breed group and protein level of the diet (Table 1).

According to Costa et al. (2009), protein is the second most required nutritional component by ruminants, and for these authors, diets with deficiency or excess protein delay or reduce the manifestation of rut, reduce conception and elevate embryo mortality. Therefore, it must be ensured that protein levels in ruminant diets are at sufficient quantities (Alemede, 2010).

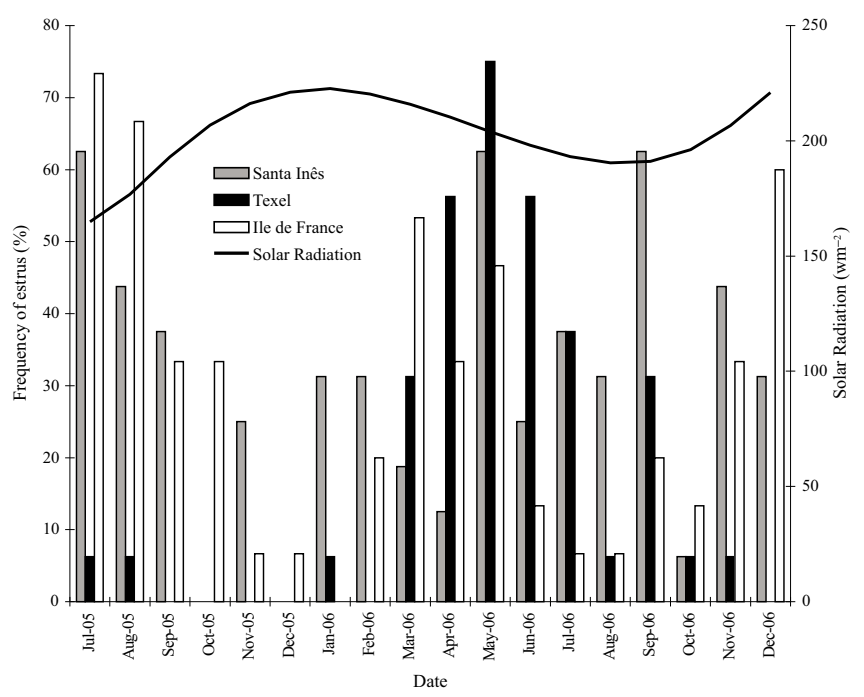

Figure 1 - Solar radiation and frequency of estrus in female Santa Inês, Texel and Ile de France sheep in the northwest of Paraná State, Brazil. 
Table 1 - Means, standard deviation and credible intervals of frequency of estrus in Santa Inês, Texel and Ile de France ewes fed 12\% crude protein

\begin{tabular}{|c|c|c|c|c|}
\hline \multirow[b]{2}{*}{ Parameters } & \multicolumn{4}{|c|}{ Bayesian estimates } \\
\hline & $\begin{array}{c}\text { Means and standard } \\
\text { deviations }\end{array}$ & $\mathrm{P}_{2.5 \%}$ & Medians & $P_{97.5 \%}$ \\
\hline$\beta_{1}$ (Santa Inês) & $-0.01428 \pm 0.01321$ & -0.044600 & -0.01296 & 0.007900 \\
\hline$\alpha_{2}$ (Texel) & $-2.47600 \pm 0.38200$ & -3.328000 & -2.44200 & -1.805000 \\
\hline$\beta_{2}^{2}($ Texel $)$ & $0.01275 \pm 0.01407$ & -0.010720 & 0.01132 & 0.045960 \\
\hline$\alpha_{3}$ (Île de France) & $-0.94380 \pm 0.33810$ & -1.586000 & -0.95380 & -0.260100 \\
\hline$\Delta_{2 \alpha}: \alpha_{1}-\alpha_{3}$ & $-0.38700 \pm 0.45900$ & -1.255000 & -0.39060 & 0.535800 \\
\hline$\Delta_{3 \alpha}: \alpha_{2}-\alpha_{3}^{*}$ & $-1.53200 \pm 0.51360$ & -2.630000 & -1.50400 & -0.616100 \\
\hline$\Delta_{1 \beta}: \beta_{1}-\beta_{2}$ & $-0.02704 \pm 0.01919$ & -0.069130 & -0.02589 & 0.006269 \\
\hline$\Delta_{2 \beta}: \beta_{1}-\beta_{3}$ & $0.01774 \pm 0.02118$ & -0.024060 & 0.01718 & 0.059210 \\
\hline$\Delta_{3 \beta}: \beta_{2}-\beta_{3}^{*}$ & $0.04478 \pm 0.02207$ & 0.007425 & 0.04280 & 0.093120 \\
\hline
\end{tabular}

*Significant difference at the level of $5 \%$.

According to the NRC (2007), the crude protein requirement for maintenance for ewes is $66 \mathrm{~g} /$ day, and for the reproductive functions, this value is $30 \%$ higher.

There were differences $(\mathrm{P}<0.05)$ between the initial frequency of estrus between Santa Inês and Ile de France breeds when compared with Texel. The statistical analysis corroborates the data presented in Figure 1, demonstrating the higher frequency of estrus in female Santa Inês and Ile de France sheep as compared with Texel ewes.

The reproductive behavior observed for the Texel breed was as expected. Ortavant et al. (1985) reported that the Texel breed presents estrus in the summer or beginning of the fall, and it ends at the end of the winter or beginning of summer. Dyrmundsson (1978) and Robinson (1981) claim that breeds originated from latitudes between $35^{\circ} \mathrm{N}$ and $35^{\circ} \mathrm{S}$ tend to display estrus all year long, while ewes from higher latitudes tend to present marked reproductive seasonality, probably due to the effects of photoperiod, temperature and radiation.

Given that there was significant effect of breed group and protein level in the diet, the frequencies of estrus were analyzed as a function of the genetic groups within each protein level.

The analysis within the level of $12 \%$ protein in the diet showed significant differences for frequency of estrus between the Santa Inês, Texel and Ile de France breeds (Figure 2).

The probability of estrus manifestation in Santa Inês and Ile de France ewes at a certain moment does not differ $(\mathrm{P}>0.05)$ between these two genetic groups, which is not true when they are compared with the Texel females, characterizing the lower probability $(\mathrm{P}<0.05)$ of finding females of this breed manifesting estrus at a given moment. In the present experiment, a short period of reproductive

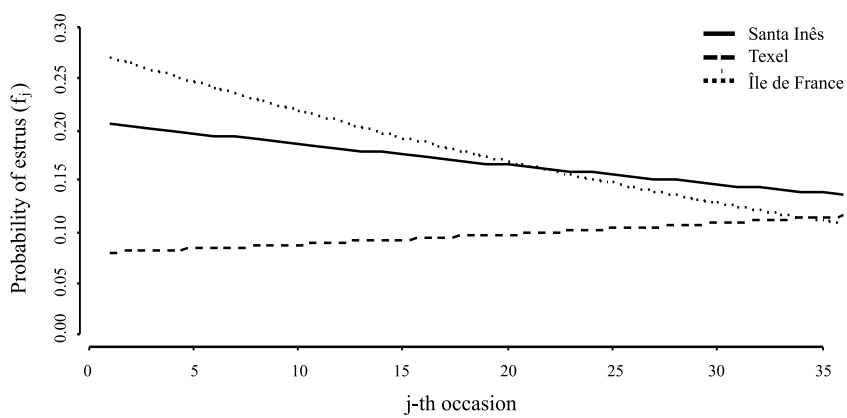

Figure 2 - Probability of estrus manifestation in female Santa Inês, Texel and Ile de France sheep receiving 2\% dietary crude protein.

seasonality was observed for Santa Inês and Ile de France ewes. According to Traldi (1990), woolless ewes do not present reproductive seasonality, contradicting the results found herein. Sasa (2006), despite considering that Santa Inês females are fertile during the entire year, reported a short reproductive-seasonality period in the city of Pirassununga/ SP, Brazil ( $21^{\circ} 59^{\prime}$ latitude and $47^{\circ} 25^{\prime}$ longitude).

Although Traldi (1990) and Sasa (2006) studied the manifestation of rut in sheep and despite the fact that the present study used lambs, it can be inferred that Sana Inês ewes were at the age and weight for puberty, according to the growth curve presented by Guedes et al. (2005), and these characteristics are similar in the Texel breed (Guimarães Filho et al., 2009). Ile de France ewes presented $66 \mathrm{~kg}$ and were at 29 months of age, which is enough for them to be at puberty according to Jainudeen et al. (2000).

The results of the Bayesian analysis, comparing the Santa Inês, Texel and Ile de France breeds on the diet with $16 \%$ CP (Table 2), showed that there were no significant differences between the breed groups as to the frequency of estrus. 
Table 2 - Means, standard deviations and credible intervals of the frequency of estrus in Santa Inês, Texel and Ile de France ewes fed 16\% of crude protein

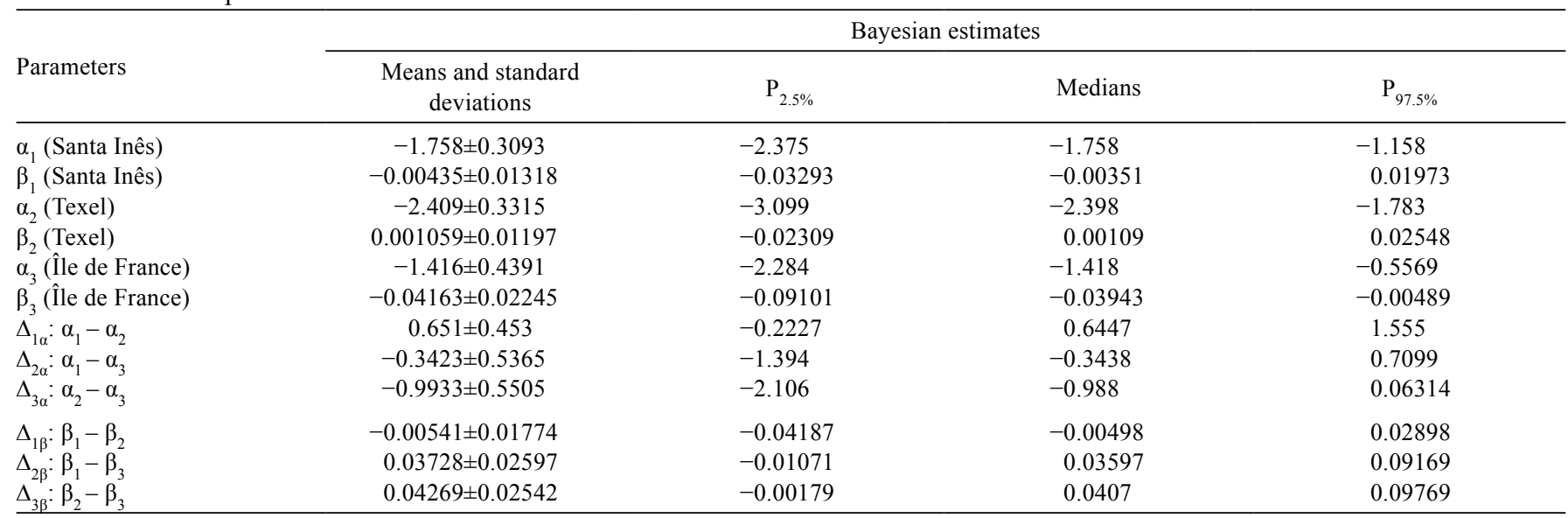

Studying ground corn + concentrate diets with $10 \%$ of crude protein in Savanna Brown ewes, Alemede (2010) verified that the hormonal contents (progesterone) were not affected by the diet, but the author recommends the incorporation of protein concentrate in ewe diets. O' Ocallaghan \& Boland (1999) state that diets with a high nutritional level after mating in ewes or cows may increase the metabolization of progesterone in the liver.

The absolute values demonstrate similar characteristics to those found in the group of animals fed $12 \% \mathrm{CP}$. However, statistically, the difference obtained in the latter did not repeat, probably because it is a high level of protein with elevated ruminal degradability which increases the ammonia concentration in the blood.

When the ewes received a higher level of crude protein, there were no significant differences $(\mathrm{P}>0.05)$ in the frequency of estrus between the genetic groups. The analyses of the effect of each protein level on the estrus incidences demonstrate that providing diets with $16 \% \mathrm{CP}$ has no effect of on this trait (Figure 3), indicating the existence of other non-identified factors, exerting an influence on the frequency of estrus in the female sheep of this feeding treatment. It is worth stressing that the lambs presented age and weight consolidated to be in puberty, which really shows that the results are effects of the seasonality on the cyclic behavior.

Increase in the dietary protein may affect the secretion of LH (Fitzgerald et al., 1982), follicular development, ovulation, formation and maintenance of the corpus luteum and impair the regulation of FSH and LH, as well as the formation of the receptors at the granulosa layer of the follicle (Darwash et al., 1999). According to O'Callaghan \& Boland (1999), the crude protein from the diet is hydrolyzed in the rumen, forming ammonia, which is used by the microorganisms to synthesize protein. However, the

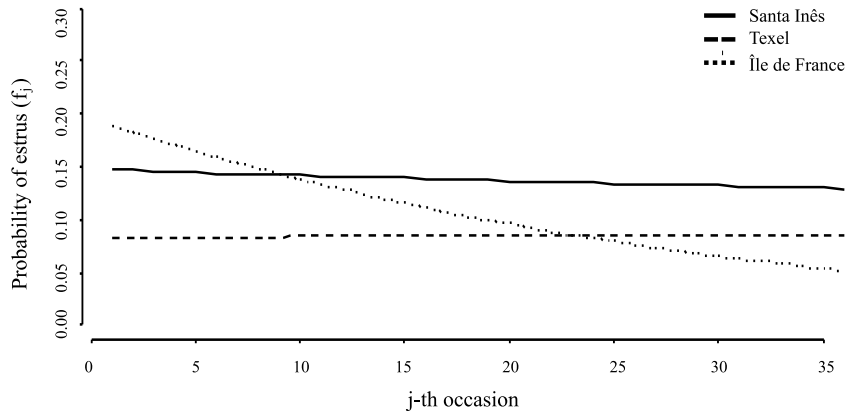

Figure 3 - Probability of manifestation of estrus in female Santa Inês, Texel and Ile de France sheep receiving 16\% dietary crude protein.

authors comment that the excess ammonia is transported to the liver to be metabolized into urea or used for the synthesis of amino acids. Thus, ingestion of elevated amounts of rumen-degradable protein increases the blood urea concentration and may affect the endocrine system, which regulates the reproductive activities. Perhaps, the level of $16 \%$ of highly-rumen-degradable crude protein elevated the secretion of estradiol, and the latter might have caused a negative-feedback effect on the synthesis of $\mathrm{LH}$ (Fitzgerald et al., 1982).

The analysis of the frequency of estrus (Table 3) did not show significant effect of the protein level in the diet, indicating that the diet with $12 \%$ crude protein is enough to maintain the cyclic behavior of the breed groups and that higher values may impair the reproductive endocrinology, which is in agreement with O'Callaghan \& Boland (1999). Boulanouar et al. (1995) studied the effect of dietary protein and energy on the onset of puberty in ewes $(1 / 2$ Finnish Landrace $+1 / 4$ Dorset $+1 / 4$ Rambouillet) and verified lower effect of protein than of energy on the beginning of puberty. 
Table 3 - Means, standard deviations and credible intervals of the frequency of estrus in Santa Inês, Texel and Ile de France ewes fed 12 or $16 \%$ crude protein

\begin{tabular}{lclcc}
\hline & & \multicolumn{3}{c}{ Bayesian estimates } \\
\cline { 2 - 5 } Parameters & $\begin{array}{c}\text { Means and standard } \\
\text { deviations }\end{array}$ & $\mathrm{P}_{2.5 \%}$ & Medians & $\mathrm{P}_{97.5 \%}$ \\
\hline$\alpha_{1}$ & $-1.341 \pm 0.2992$ & -1.915 & -1.348 & -0.7303 \\
$\beta_{1}$ & $-0.01403 \pm 0.01288$ & -0.04243 & -0.01279 & 0.008092 \\
$\alpha_{2}$ & $-1.76 \pm 0.3068$ & -2.361 & -1.761 & -1.158 \\
$\beta_{2}$ & $-0.00438 \pm 0.01307$ & -0.03278 & -0.00358 & 0.01929 \\
$\Delta_{\alpha}: \alpha_{1}-\alpha_{2}$ & $0.4191 \pm 0.4303$ & -0.4015 & 0.4179 & 1.28 \\
$\Delta_{\beta}: \beta_{1}-\beta_{2}$ & $-0.00965 \pm 0.01842$ & -0.04712 & -0.00931 & 0.02651 \\
\hline
\end{tabular}

Gordon (1997) concluded that breeds from both temperate and tropical climate origins are minimally influenced by the nutritional level. In the present study, it could be verified that female sheep fed 12 or $16 \%$ crude protein in the diet did not differ $(\mathrm{P}>0.05)$ as to the manifestation of estrus, suggesting that feeding was not a determinant factor in changing the frequency of estrus in these animals.

Aiming to corroborate the results obtained with the identification of ewes under estrus marked by the teaser rams in laboratory, blood plasma samples were collected from Santa Inês females in periods when the frequency of estrus was low. Blood plasma samples of the referred months of 2005 and 2006 were analyzed to determine the plasma progesterone concentration (Table 4).

Based on the descriptive analysis of the data, it was verified that the months of October, November and December 2005 were those of lowest estrus manifestation for Santa Inês females. The results indicate that there was difference $(\mathrm{P}<0.05)$ between years, which could also be verified in the descriptive analysis of the estrus manifestation, validating the data corresponding to the period in which the lowest frequencies of estrus in Santa Inês ewes were verified.

Working with Santa Inês ewes, Sasa (2006) evaluated a lot with 10 animals between September 2002 and August 2003 and observed the average plasma progesterone

Table 4 - Effect of dietary crude protein levels and year on the average plasma progesterone concentration in Santa Inês ewes

\begin{tabular}{lc}
\hline Item & Progesterone concentration $(\mathrm{ng} / \mathrm{mL})$ \\
\hline Diet & \\
$12 \%$ crude protein & $0.68 \mathrm{a} \pm 1.32(220)$ \\
$16 \%$ crude protein & $1.28 \mathrm{~b} \pm 1.99(221)$ \\
Year & \\
2005 & $0.39 \mathrm{a} \pm 0.78(205)$ \\
2006 & $1.47 \mathrm{~b} \pm 2.08(236)$ \\
\hline
\end{tabular}

Means within each class, followed by lowercase letters in the rows, differ according to the Tukey test at $5 \%$.

Values in parentheses are the number of samples analyzed. concentration in the different seasons of the year. In the season corresponding to that evaluated in the present experiment, Sasa (2006) found $1.9 \mathrm{ng}$ progesterone $/ \mathrm{mL}$, whereas in the present experiment it was $1.47 \mathrm{ng} / \mathrm{mL}$ for 2006 and $0.39 \mathrm{ng} / \mathrm{mL}$ for the spring of 2005, which was the season when the lowest frequencies of estrus were found. Coelho et al. (2002) report plasma progesterone concentrations in Santa Inês ewes of $0.45 \mathrm{ng} / \mathrm{mL}$ during estrus and up to $4.3 \mathrm{ng} / \mathrm{mL}$ during diestrus. Sasa (2006) noticed a period of reproductive anestrus in six of the ten ewes used in his experiment, but in the present experiment, it was verified with a higher intensity.

According to the analyses of progesterone and the protein levels, greater average concentration of progesterone was observed in animals fed diets with $16 \%$ crude protein (Table 4 ). Feeding a diet with corn and another with concentrate containing $10 \%$ crude protein to young goats, Alemede (2010) observed higher plasma progesterone concentration in those fed concentrate. Contrastingly, Michell et al. (1997) did not verify influence of dietary protein on the blood progesterone level of 4.5-year-old ewes in the reproductive season, which was above $1 \mathrm{ng} / \mathrm{mL}$. The results of this last author differ from the observed herein; there are divergences as to the influence of the dietary protein level on the blood progesterone concentration. Perhaps, factors like breed, environment, age of females, ingredients that make up the diets, moment of the estrus cycle in which the blood samples were collected and reproductive stage when the samples were obtained may generate variations between studies.

\section{Conclusions}

In the northeast of Paraná State, Brazil, at $23^{\circ} 25^{\prime}$ south longitude, $51^{\circ} 55^{\prime}$ west longitude and $554.9 \mathrm{~m}$ altitude, Santa Inês ewes do not present estrus in the months of October, November and December and Ile de France do not manifest estrus in January. Texel females show low frequency or absence of estrus from July to February. The levels of 12 
and $16 \%$ of crude protein in the diet do not change the frequency of estrus in Santa Inês, Ile de France or Texel ewes; the recommended crude protein dose to be adopted is $12 \%$.

\section{References}

AANES, W.A.; RUPP, G. Iatrogenic prepucial stenosis of preparation of teaser bulls. Journal of the American Veterinary Medical Association, v.184, p.1474-1476, 1984.

ALEMEDE, I.C. Blood progesterone level of intensively managed savanna brown does fed maize and protein concentrate diet. Pakistan Journal of Nutrition, v.9, n.1, p.100-102, 2010.

BEST, N.G.; COWLES, M.K.; VINES, S.K. CODA: Convergence diagnostics and output analysis software for Gibbs sampler output. Version 0.3. Cambridge: MCR Biostatistics Unit, 1995.

BOULANOUAR, B.; AHMED, M.; KLOPFENSTEIN, T. et al. Dietary protein or energy restriction influences age and weight at puberty in ewe lambs. Animal Reproduction Science, v.40, p.229-238, 1995.

COELHO, L.A.; RODRIGUES, P.A.; SASA, A. et al. Concentrações plasmáticas de progesterona em borregas lanadas e deslandas durante a estação reprodutiva. Revista Brasileira de Zootecnia, v.31, n.3, p.1150-1156, 2002.

CORRÊA, A.R. Forrageiras: aptidão climática do Estado do Paraná. In: MONTEIRO, A.L.G.; MORAES, A.; CORRÊA, E.A.S. et al. (Eds.) Forragicultura no Paraná. Londrina: CPAF, 1996. p.15-22.

COSTA, D.P.B.; RICARDO, H.A.; VIERA, A.O. et al. [2009]. Relação entre níveis de proteína na dieta e a fertilidade de vacas e ovelhas. Pubvet, v.3, n.32, 2009. Available at: $<$ http://pubvet.com. br/artigos imp.asp? $=538>$ Accessed on: July 15, 2011.

DARWASH, A.O.; LAMING, G.E.; WOOLLIAMS, J.A. The potential for identifying heritable endocrine parameters associated with fertility in post-partum dairy cows. Animal Science, v.68, n.2, p.333-347, 1999.

DYRMUNDSSON, O.R. Studies on breeding season of Iceland ewes and ewe lambs. Journal of Agriculture Science, v.90, p.275-281, 1978.

FITZGERARD, J.; MICHEL, F.; BUTLER, W.R. Growth and sexual maturation in ewes: dietary and seasonal effects modulating luteinizing hormone secretion and first ovulation. Biology of Reproduction, v.27, p.864-870, 1982.

FORCADA, F.; ABECIA, J.A.; SIERRA, I. Seasonal changes in oestrous activity and ovulation rate in Rasa Aragonesa ewes maintained at two different body condition levels. Small Ruminant Research, v.8, p.313-324, 1992.

GALINA, M.A.; MORALES, R.; SILVA, E. et al. Reproductive performance of Pelibuey and Blackbelly sheep under tropical management systems in Mexico. Small Ruminant Research, v.22, p.31-37, 1996.

GEWEKE, J. Evaluating the accuracy of sampling-based approaches to the calculation of posterior moments. In: BERNARDO, J.M.; DAVID, P.A.; SMITH, A.F.M. (Eds.). Bayesian statistics 4. Oxford: Oxford University Press, 1992. p.169-194.

GOLDMAN, B.D. The circadian timing system and reproduction in mammals. Steroids, v.64, n.9, p.679-685, 1999.

GORDON, I.R. Controlled reproduction in sheep and goats. Wallingford, UK: CAB International, 1997. 450p.
GUEDES, M.H.P.; MUNIZ, J.A.; SILVA, F.F. et al. Análise Baysiana da curva de crescimento de cordeiros da raça Santa Inês. Arquivo Brasileiro de Medicina Veterinária e Zootecnia, v.57, n.3, p.415-417, 2005.

GUIMARÃES FILHO, C.; ATAIDE JÚNIOR, J.R. Manejo básico de ovinos e caprinos: Guia do educador. Brasília: SEBRAE, 2009. 148p.

HEIDELBERGER, P.; WELCH, P.D. Simulation run length control in the presence of an initial transient. Operations Research, v.31, n.6, p.1109-1144, 1983.

JAINUDEEN, M.R.; WAHID, H.; HAFEZ, E.S.E. Sheep and goats. In: HAFEZ, B.; HAFEZ, E.S.E. (Eds.) Reproduction in farm animals. 7.ed. Philadelphia: Lippincott Williams \& Wilkins, 2000. p.172-181.

LOURENÇO, F.J. Utilização de diferentes métodos para deteç̧ão do comportamento endoparasitário em fêmeas ovinas de diferentes grupos raciais. 2006. 63f. Dissertação (Mestrado em Zootecnia) - Universidade Estadual de Maringá, Maringá.

MICHELL, L.M.; KING, M.E.; GEBBIE, F.E. et al. Effect of age and dietary protein content $\mathrm{n}$ post-partum oestruscyclicity in ewes lambing within their natural breeding season. Livestock Production Science, v.50, n.1, p.97-98, 1997.

NATIONAL RESEARCH COUNCIL - NRC. Nutrients requirements of sheep. Washington: National Academy Press, 1985. 99p.

NATIONAL RESEARCH COUNCIL - NRC. Nutrient requeriments of small ruminants: Sheep, gots, cervids and new worldscamelids. Washington: National Academic Press, 2007. 384p.

O'CALLAGHAN, D.; BOLAND, M.P. Nutritional effects on ovulation, embryo development and the establishment of pregnancy in ruminants. Animal Science, v.68, n.2, p.299-314, 1999.

ORTAVANT, R.; PELLETIER, J.; RAUVAULT, J.P. et al. Photoperiod: main proximal and distal factor of the circannual cycle of reproduction in farm mammals. In: CLARKE, J.R. (Ed.) Oxford reviews of reproductive biology. Oxford: Oxford University Press, 1985. v.7, p.305-345.

RHIND, S.M. Nutrition: its effect on reproductive performance and its control in female sheep and goats. In: Progress in sheep and goat research. Wallingford: CAB International, 1992. p.25-52.

ROBINSON, J.J. Photoperiodic and nutritional influence on the reproductive performance of ewes in accelerated lambing systems. In: ANNUAL MEETING OF THE EUROPEAN ASSOCIATION FOR ANIMAL PRODUCTION, 32., 1981, Zagreb. Proceedings... Zagreb, 1981. v.III-2. p.1-10.

ROBINSON, J.J. Nutrition and reproduction. Animal Reproduction Science, v.42, p.25-34, 1996.

RODA, D.S.; SANTOS, L.E.; CUNHA, E.A. et al. Desempenho de ovinos em sistema de acasalamento a cada oito meses. Boletim da Indústria Animal, v.50, n.1, p.49-54, 1993.

SASA, A. Perfis sazonais das concentrações plasmáticas de progesterona, prolactina e melatonina de ovelhas criadas em baixas latitudes. 2006. 50f. Tese (Doutorado em Zootecnia) Universidade de São Paulo, Pirassununga.

SILVA, A.E.D.F.; FOOTE, W.C.; RIERA, G.S. et al. Efeito do manejo nutricional sobre a taxa de ovulação e folículos, no decorrer do ano, em ovinos deslanados no nordeste do Brasil. Pesquisa Agropecuária Brasileira, v.22, n.6, p.635-645, 1987.

SPIEGELHALTER, D.J.; THOMAS, A.; BEST, N. etal. BUGS- Bayesian inference using gibbs sampling. Version 0.50. Cambridge: MRC Bioestatistics Unit., 1995.

TRALDI, A.S. Aspectos reprodutivos dos ovinos. Performance reprodutiva dos ovinos deslanados no Brasil. In: Produção de ovinos. Jaboticabal: FUNEP, 1990. p.81-124. 